\title{
I'JAZUL QUR'AN
}

Dea (191370018)

Mahasiswi Jurusan Ilmu Hadits A Semester 3 UIN SMH BANTEN

Email: dea13102001@gmail.com

\author{
FAKULTAS USHULUDIN DAN ADAB
}

\section{UNIVERSITAS ISLAM NEGERI SULTAN MAULANA HASANUDDIN BANTEN}

TAHUN 2021

\begin{abstract}
Extraordinary events that surpass the ability of the human senses to understand it in Islamic literature are called miracles. Miracles become one of the signs of the truth of a prophet sent by Allah SWT. The Qur'an is the greatest miracle given to the last prophet, the Prophet Muhammad. By the scholars of the Koran there have been various studies on the extraordinary aspects contained in the Koran. They found many amazing things in it. So as to provoke other researchers to uncover and reveal other extraordinary sides contained in it. This brief article narrates some of the extraordinary aspects contained in the Qur'an that have been studied by experts in their fields.
\end{abstract}

Keywords: Alquran, Mu'jizat 


\begin{abstract}
Abstrak
Kejadian luar biasa yang melampaui kemampuan indera manusia untuk memahaminya dalam literature keislaman disebut dengan mukjizat. Mukjizat menjadi salah satu tanda kebenaran seorang nabi yang diutus oleh Allah swt. Alquran adalah mukjizat terbesar yang diberikan kepada nabi terakhir yaitu nabi Muhammad saw. Oleh para pakar ilmu Alquran telah dilakukan berbagai penelitian tentang aspek-aspek luar biasa yang terdapat di dalam Alquran. Mereka menemukan banyak hal yang menakjubkan di dalamnya. Sehingga memancing para peneliti lain untuk mengungkap dan menyingkap sisi-sisi luar biasa lainnya yang terdapat di dalamnya. Tulisan singkat ini menarasikan beberapa aspek luar biasa yang terdapat dalam Al qur'an yang telah diteliti oleh para ahli dalam bidangnya.
\end{abstract}

Kata kunci: Al-Qur'an, Mu'jizat

\title{
Pendahuluan
}

Setiap nabi dan rasul mempunyai kejadian luar bisa yang tidak bisa dijangkau oleh nalar manusia. Kejadian tersebut dikenal dengan mu'jizat. Di antara para nabi dan rasul yang pernah diberikan mu'jizat oleh Allah swt adalah nabi ibrahim, nabi musa, nabi Isa dan nabi Muhammad saw. Nabi Ibrahim terkenal dengan mu'jizatnya selamat dari api ketika beliau dicampakkan oleh tentara raja namruz yang ingkar terhadap ajaran yang dibawanya. Nabi musa terkenal dengan mu'jizat dapat membelah laut ketika beliau dikejar oleh pasukan raja Fir'aun. Di samping itu banyak juga mu'jizat lain yang diberikan kepada nabi Musa.

Al qur'an adalah mu'jizat yang terbesar yang diberikan kepada Nabi Muhammad saw. Di samping Al qur'an nabi Muhammad juga menerima mu'jizat lainnya. Al qur'an diturunkan di tengah-tengah umat yang sedang mengelu-elukan para penyair-penyair jahiliyah di wilayah mekkah dan sekitarnya. Para penyair yang mampu memenangkan sayembara syair arab jahiliyah akan merasa sangat tersanjung karena hal itu merupakan prestasi yang sangat membanggakan di masa itu. Hasil karya pemenang syair arab tersebut dipublikasi di dinding ka'bah sebagai wujud apresiasi kepada pemenang sayembara. 
Ketika Al qur'an turun kaum Quraisyh yang hidup dengan tradisi yang sudah turun temurun merasa terheran-heran dengan keindahan gaya bahasa Al qur'an. Tidak sedikit di antara mereka yang menganggap Al qur'an adalah sihir. Namun di sisi lain justru keindahan bahasa Alquran menjadi penarik kaum musyrikin Quraisyh untuk mempelajarinya bahkan berujung kepada beriman terhadap ajarannya.

Al qur'an juga terjaga dari pertentangan didalamnya, semuanya itu merupakan bukti bahwa Al qur'an itu memang benar kalam Allah swt. Lalu bagaimana kita dapat mengetahui kemukjizatan Al qur'an mengingat kemukjizatannya berbeda dengan mukjizat rasul-rasul terdahulu yang bersifat indrawi. ${ }^{1}$

Tulisan singkat ini akan memaparkan beberapa sisi kemu'jizatan Al qur'an dalam berbagai sudut pandang serta akan mengulas bagaimana pembelaan ummat Islam terhadap kitab suci mereka terhadap para penentangnya. Kajian ini akan mendeskripsikan hal tersebut dengan merujuk kepada pendapat beberapa pakar dalam berbagai sumber serta menganalisa berbagai persoalan kekinian terkait dengan Alquran tentunya akan dikorelasikan dengan beberapa kejadian di masa lalu (historis) seputar reaksi umat terhadap para penghina Al qur'an.

\section{Pengertian I'jazul Qur'an}

Secara etimologis kata عجاز ('jaz) berasal dari akar kata عجز ('ajun )artinya tidak mampu/kuasa. Kata عجزadalah jenis kata yang tidak memiliki muatan aktifitas (pasif). Kemudian kata ini dapat berkembang menjadi kata kerja aktif supaya dengan wajan (af'ala) (a`jaza-yu’jizu) berarti melemahkan, dengan demikian, Al-Qur`an sebagai mukjizat bermakna bahwa AI-Qur`an merupakan sesuatu yang mampu melemahkan tentang menciptakan karya yang serupa dengannya. ${ }^{2}$ Dalam kamus besar bahasa Indonesia, "kata mukjizat" diartikan sebagai kejadian luar biasa yang sukar dijangkau oleh akal pikiran manusia. Pengertian ini punya muatan yang berbeda dengan pengertian i jaz dalam perspektif islam. ${ }^{3}$ I jaz sesungguhnya menetapkan kelemahan ketika mukjizat telah terbukti, maka yang nampak kemudian adalah kemampuan atau "mu jiz" [yang melemahkan], oleh sebab itu i’jaz AI-Qur’an menampakan kebenaran Muhammad SAW dalam pengakuannya sebagai rosul yang memperlihatkan

\footnotetext{
${ }^{1}$ Badrudin,"I'jaz Al-qur'an",Hal.135,Kota Serang

${ }^{2}$ H.Muh.quraish syihab dkk, sejarah \& ulum al-qur'an (Jakarta: Pustaka Firdaus, 1999), hlm.106

${ }^{3}$ Quraish syihab, mukjizat al-qur'an dan aspek kebahasaan, isyarat ilmiah dan pemberitaan yang ghaib ( bandung: mizan 1998),cet.IV, hlm.23.
} 
kelemahan manusia dalam menandingi mukjizatnya. Kemukjizatan menurut persepsi ulama harus memenuhi kriteria 5 syarat sebagai berikut:

1. Mukjizat harus berupa sesuatu yang tidak di sanggupi oleh makhluk sekalian alam.

2. Tidak sesuai dengan kebiasaan dan tidak berlawanan dengan hukum islam.

3. Mukjizat harus berupa hal yang dijadikan saksi oleh seorang mengaku membawa risalah ilahi sebagai bukti atas kebenaran dan kebesarannya.

4. Terjadi bertepatan dengan penagakuan nabi yang mengajak bertanding menggunakan mukjizat tersebut.

5. Tidak ada seorang pun yang dapat membuktikan dan membandingkan dalam pertandingan tersebut.

Sedang yang di maksud dengan i’jaz secara terminology ilmu AI-Qur`an sebagaimana yang dikemukakan oleh beberapa ahli sebagai berikut:

1. Menurut Manna' Khalil Al-Qhatan

I'jaz adalah menampakkan kebenaran nabi SAW dalam pengakuan orang lain sebagai rasul utusan Allah SWT dengan menampakan kelemahan orang-orang Arab untuk menandinginya atau menghadapi mukjizat yang abadi. Yaitu AL Qur`an dan kelemahankelemahan generasi sesudah mereka. ${ }^{4}$

2. Menurut Ali Al-Shabuni

I jaz ialah menetapkan kelemahan manusia baik secara kelompok maupun bersamasama untuk menandingi hal yang serupa dengannya, maka mukjizat merupakan buktiyang datangnya dari Allah SWT yang di berikan kepada hamba-Nya.

Mukjizat adalah perkara yang luar biasa yang disertai dengan tsantangan yang tidak mungkin dapat ditandingi oleh siapapun dan kapanpun. Muhammad Bakar ismail menegaskan, mukjizat adalah perkara luar biasa yng di sertahin dan di ikuti tantangan yng di berikan oleh Allah Swt kepada nabi-nabi sebagai hujjah dan bukti yang kuat atas misi dan kebenaran terhadap apa yang di embannyah yang bersumber dari Allah swt.

Dari kedua definisi di atas dapat di pahami antara i'jaz dan mukjizat itu dapat di katakan melemakan. Hanya saja pengertian I'jaz di atas mengesankan Batasan yang lebih spesifik, yaitu

\footnotetext{
${ }^{4}$ Manna khalli al-qattan, studi ilmu-ilmu al-qur'an (terjemahan dari mubahits fiulumil qur'an), (Jakarta: putaka litera antar musa, 2004), hlm.371
} 
Al-Qur'an. Sedangkan pengertin mukjizat itu dapat, menegaskan Batasan yang lebih luas, yakni bukan hanya berupa Al-Qur'an, tetapi juga perkara-perkara lain yang tidak mampu di jangkau manusia secara keseluruhan. Dengan demikian dalam konteks ini antara pengertian I'jaz dan mukjizat itu saling melengkapi, sehingga nampak jelas keistimewaan dari ketetapan-ketetapan Allah yang khusus di berikan kapada Rasul-rasulnya pilihan-nya sebagai salah satu bukti kebenaran misi kerasulan yang di bawanya. ${ }^{5}$

Di tampilkan I'jaz atau mukjizat itu bukanlah semata-semata bertujuan untuk menampakan kelemahan manusia untuk menandinginya tetapi untuk menyakinkan mereka bahawa Nabi Muhammad saw, adalah benar-benar utusan Allah, Al-Qur'an itu benar-benar diturunkan di sisi Allah swt. Kepada Muhammad yang mana Al-Qur'an itu sama sekali bukanlah perkataan manusia atau perkataan lainnya.

Al-Qur'an di gunakan oleh nabi muhamad saw untuk menantang orang-orang pada masa beliau dan generasi sesudanya tidak percaya akan kebenaran Al-Qur'an sebagai firman Allah (bukan ciptaan Muhammad) dan tidak percaya akan risalah nabi saw dan ajaran yang di bawanya. Terhadap mereka sesungguhnya mereka memiliki tingkat fashahah dan balaghah sedemikian tinggi di bidang bahasa Arab. Nabi meminta mereka untuk menadingi Al-Qur'an dalam tiga tahapan. ${ }^{6}$

Kelahiran ilmu kalam di dalam islam mempunyai implikasi lebih tepat untuk di katakan sebagai kalam. Di dalam kalam, dimana tokoh-tokoh ilmu kalam tampak ketika membicarakan kemakhlukan Qur'an maka pendapat dan pandangan mereka berbeda-beda dan beraneka ragam. ${ }^{7}$

Menurut Abu Ishaq Ibrahim an-Nizam dan pengikutnya dari kaum syi'ah berpendapat, kemukjizatan Qur'an adalah dengan cara sirfah (pemalingan ).Arti sirfah dalam pandangan anNizam ialah bahwa Allah memalingkan orang-orang Arab untuk menentang Qur'an, padahal sebenarnya mereka mampu menghadapinya. Pendapat tentang sirfah ini batil dan di tolak oleh Qur'an sendiri. Dalam firmannya:

\footnotetext{
${ }^{5}$ Usman, ulumul qur'an hlm.287

${ }^{6}$ M. Quraish shihab, mukjizat al-qur'an, (bandung: mizan, 1997), hlm.23

${ }^{7}$ Manna Khalil al-qattan, studi ilmu-ilmu, hlm.374-377
} 
"Katakanlah, sesunggunya jika manusia dan jin berkumpul untuk membuat yang serupa $\mathrm{Al}$ Qur'an ini, niscaya mereka tidak akan dapat membuat yang serupa denganya sekalipun Sebagian mereka menjadi pembantu bagi yang Sebagian lagi” (QS.Al-Isra :88)

Ayat ini menunjukan bahwa mereka tidak tidak mampu memenuhi tantangan, padahal kemampuan ada pada diri mereka. Jika kemampuan itu di rampas dari mereka, niscaya tidak ada faedah dari perkumpulan mereka itu. Karena kedudukannya akan sama ,dengan perkumpulan orang-orang mati. Dan ketidak mapuan orang-orang mati bukanlah merupakan sesuatu yang perlu di besar-besarkan penyebutannya. ${ }^{8}$

Setelah para ulama'sepakat bahwasanya kemukjizatan Al-Qur'an itu karena dzatnya, serta tidak seorang pun yang sanggup mendatangkan sesamanya, maka pandangan ulama berbeda-beda dalam meninjau segi kemukjizatannya itu seperti di bawah ini :

1. Satu golongan ulama berpendapat Qur'an itui mukjizat dengan balaghah-Nya yang mencapai tingkat tinggi dan tidak ada bandinganya.

2. Sebagian yang lain berpendapat segi kemukjizatannya Al-Qur'an itu ialah karena mengandung badi' yang sangat unik dan berbeda dengan apa yang di kenal dalam perkataan orang Arab.

3. Golongan yang lain berpendapat bahwa Al-Qur'an itu terletak pada pemberitaanya tentang hal-hal ghaib yang akan datang yang tidak dapat di ketahui kecuali dengan wahyu.

4. Satu golongan berpendapat Al- Qur'an itu mukjizat karena ia mengandung bermacammacam ilmu hikmah yang sangat dalam.

\section{Macam-macam Kemukjizatan Al-Qur'an}

Macam-macam Ijaz al-Qur'an Secara garis besarnya, i'jaz dapat dibagi ke dalam dua bagian pokok, yaitu:

\footnotetext{
${ }^{8}$ Imam suyuti, ulumul qur'an terj. Al-itqon fi ulumil qur'an (Surakarta: indiva Pustaka, 2009), hlm.667
} 
Pertama, mukjizat yang bersifat material inderawi lagi tak kekal, dan kedua, mukjizat immaterial, logis lagi dapat dibuktikan sepanjang masa". ${ }^{9}$ Untuk lebih jelas akan dijelaskan dari kedua bagian pokok berikut ini :

1. Mu'jizat material inderawi

Mukjizat para nabi terdahulu sebelum Nabi Muhammad saw. semuanya merupakan jenis "Mukjizat material inderawi". Mukjizat yang dimiliki oleh para nabi tersebut, dapat langsung disaksikan oleh mata telanjang atau dapat ditangkap oleh indera mata, tanpa perlu dianalisa. Namun peristiwa tersebut hanya ada dan terbatas pada kaum (masyarakat) di mana seorang nabi tersebut diutus.

Pada dasarnya, keluarbiasaan yang diberikan Allah kepada para nabi terdahulu tersebut merupakan jawaban atas tantangan yang dihadapkan kepada mereka oleh pihakpihak lawan, misalnya: perahu Nabi Nuh as. yang dibuat atas petunjuk Allah sehingga mampu bertahan dalam situasi dalam ombak dan gelombang yang sedemikian dahsyat, tidak terbakarnya Nabi Ibrahim as. dengan dilemparkan dalam kobaran api yang sangat besar, tongkat Nabi Musa as. beralih wujud menjadi ular, penyembuhan yang dilakukan oleh Nabi Isa as. terhadap berbagai macam penyakit atas izin Allah dan lain-lain. ${ }^{10}$ Semua mukjizat tersebut hanya bersifat inderawi siapapun tidak bisa menolak, namun terbatas bagi masyarakat di tempat para nabi menyampaikan risalahnya, dan berakhir dengan wafatnya nabi-nabi tersebut.

2. Mu'jizat immaterial logis dan kekal

Adapun mukjizat yang diberikan kepada Nabi Muhammad Saw yaitu mu'jizat yang bersifat immaterial logis dan kekal, yaitu berupa al-Qur'an. Hal ini dimaksudkan bahwa Nabi Muhammad diutus kepada seluruh umat manusia hingga akhir zaman. Al-Qur'an sebagai bukti kebenaran ajarannya, ia harus siap untuk disajikan kepada semua orang, kapanpun, tanpa mengenal batas waktu, situasi, dan kondisi apapun. ${ }^{11}$

Hal ini seiring dengan berjalannya waktu setiap manusia mengalami perkembangan dalam pemikirannya. Sebagaimana yang dikatakan oleh Auguste Comte sebagaimana

\footnotetext{
${ }^{9}$ Ibid, hal. 43.
}

$10 \mathrm{Ibid}$, hal. 36.

${ }^{11}$ Shihab, Mu'jizat hal. 36. 
yang dikutip oleh Quraish Shihab tentang fase-fase perkembangan pikiran manusia, yaitu:

a. Fase keagamaan, karena keterbatasan pengetahuan manusia tentang menafsirkan tentang semua gejala yang terjadi, dikembalikan kepada kekuasaan Tuhan atau jiwa yang tercipta dalam pikirannya masing-masing.

b. Fase metafisika, semua fenomena atau kejadian dikembalikan pada awal kejadian, misalnya: manusia pada awal kejadiannya.

c. Fase ilmiah, manusia dalam menafsirkan fenomena melalui pengamatan yang teliti dan penelitian sehingga didapat sebuah kesimpulan tentang hukum alam yang mengatur semua fenomena alam ini. Bila alQur'an tidak logis dan tidak dapat diteliti kebenarannya melalui metode ilmiah maka membuat manusia ragu akannya atau akan ada yan mengatakan bahwa al-Qur'an tidak berguna lagi tidak bisa dipakai pada saat ini. Hal ini tidak boleh terjadi pada sebuah mu'jizat yang disiapkan untuk sekarang sampai akhir zaman. ${ }^{12}$

\section{Segi-segi Kemukjizatan Al-Qur'an}

1. Segi Kebahasaan

Kendatipun Al-Qur'an,hadits qudsi dan hadits nabawi sama-sama keluar dari mulut Nabi tetapi uslub atau susunan bahasanya sangat jau berbeda. Al-Qur'an muncul dengan uslub yang begitu indah. Uslub bahasa Al-Qur'an jauh lebih tinggi kualitasnya bila di bandingkan dengan lainnya. Dalam Al- Qur'an, banyak ayat yang maenagandung tasybih (penyerupaan ) yang di susun dalam bentuk bahasa yang sangat indah lagi mempesona, jauh lebih indah dari pada apa yang di buat oleh penyair dan sastrawan. Contoh dalam surat Al-Qori'ah (101) ayat 5, Allah berfirman : Kemukjizatannya Al-Qur'an dari segi bahasanya bisa kita liat dari tiga hal yaitu :

Nada dan langgamnya

Ayat-ayat Al-Qur'an bukanlah syair atau puisi tetapi kalau kita denger akan nampak keunikan dalam irama dan ritmenya. Hal ini di sebabkan oleh huruf dari katakata yang di pilih melahirkan keserasianya bunyi dan kemudian kumpulan kata-kata itu melahirkan pula keserasianya irama dalam rangkaian kalimat ayat-ayatnya.

12 Ibid, hal. 37 
Singkat dan padat

Dalam Al-Qur'an banyak kita jumpai ayat-ayatnya singkat tetapi padat artinya,sehingga menyebabkan berbagai macam pemahaman dari setiap mereka yang membacanya.

Memuaskan para pemikir kebanyakan orang

Bagi orang awam, ayat Al-Qur'an mungkin terasa biasa, tetapi bagi para filosof dengan ayat yang sama akan melahirkan pemahaman yang luar biasa.

2. Hukum illahi yang sempurna

Al-Qur'an menjelaskan pokok akidah, norma-norma keutamaan, sopan-santun undang-undang, ekonomi, politik, sosial, dan kemasyarakatan, serta hukum-hukum ibadah. Apabilah kita memperhatikan pokok-pokok ibadah, kita akan memperoleh kenyataan bahwa Islam telah memperluasnya dan menganekaragamkan serta meramunya menjadi ibadah amaliyah, seperti zakat dan sedekah. Ada juga yang berupa ibadah amaliyah sekaligus ibadah badaniyah, seperti berjuang di jalan Allah.

Tentang akidah Al-Qur'an mengajak umat manusia pada akidah yang suci dan tinggi, yakni beriman kepada Allah yang maha Agung, menyatakan adanya nabi dan rasul serta mempercayai kitab samawi. Dalam bidang undang-undang ,Al-Qur'an telah menetapkan kaidah-kaidah mengenai perdata, pidana, politik, dan ekonomi.Adapun mengenai hubungan internasional, Al-Qur'an telah menetapkan dasar-dasar yang paling sempurna dan adil, baik dalam keadaan damai maupun perang. Al-Qur'an menggunakan du acara tatkala menetapkan sebuah ketentuan hukum.

$>$ Secara global, persoalan ibadah umumnya di terangkan secara global, sedangkan perinciannya di serahkan kepada para ulama melalui ijtihad.

$>$ Hukum yang di jelaskan secara terperinci adalah yang berkaitan dengan utangpiutang, makanan yang halal dan yang haram, memelihara kehormatan wanita, dan masalah perkawinan.

3. Gaya bahasa

Gaya bahasa Al-Qur'an membuat orang Arab pada saat itu merasa kagum dan terpesona. Al-Qur'an secara tegas menentang semua sastrawan pada orator Arab untuk menandingi ketinggian Al-Qur'an baik bahasa maupun susunanya. Setiap kali mereka mencoba menandingi, mereka mengalami kesulitan dan kegagalan dan bahkan mencapat 
cemoohan dari masyarakat. Diantara pendusta dan musyrik Arab pada saat itu yang berusaha untuk menandingi ialah musailimah Kadzazab dan tokoh-tokoh masyarakat Arab lain pada waktu itu yang ingin menandingi kalam Allah itu, namun selalu mengalami kegagalan.

4. Berita tentang hal-hal yang ghaib

Sebagian ulama mengatakan bahwa mukjizat Al-Qur'an itu adalah berita-berita ghaib. Firaun, yang mengejar-ngejar musa, di ceritakan dalam surat Yunus (10) ayat 92 Allah berfirman yang artinya :

"Maka pada hari ini kami selamatkan badanmu supaya kamu dapat menjadi pelajaran bagi orang-orang yang datang sesudahnya dan sesunggunya kebanyakan dari manusia lengah dari tanda-tanda kekuatan kami."

Cerita peperangan Romawi dengan Persia yang di jelaskan dalam surat Ar-rum (30) ayat 1-5 merupakan satu berita ghaib lainnya yang di sampaikan Al-Qur'an, Allah berfirman yang artinya:

"Alif Laam Miim. Telah di kalahkan bangsa Romawi, di negeri yang terdekat dan mereka sesudah di kalahkan itu akan menang, dalam beberapa tahun lagi. Bagi Allah lah urusan sebelum dan sesudah mereka menang. Dan di hari kemenangan bangsa Romawi itu bergembiralah orang-orang yang beriman, karena pertolongan Allah. Dia menolong siapa saja yang di kehendaki-Nya."

5. Isyarat-isyarat ilmiah

Banyak sekali isyarat ilmiah yang di temukan dalam Al-Qur'an misalnya:

a. Cahaya matahari bersumber dari dirinya dan cahaya bulan merupakan pantulan sebagaimana yang di jelaskan firman Allah berikut yang artinya:

"Dia-lah yang menjadikan matahari bersinar dan bulan bercahaya dan di tetapkanNya munzilah-munzilah (tempat-tempat) bagi perjalan bulan itu, supaya kamu mengetahui bilangan tahun dan perhitungan (Waktu). Allah tidak menciptakan yang demikian itu, melainkan dengan hak. Dia menjelaskan tanda-tanda (kebesaran Nya) kepada orang-orang yang mengetahui." (QS.Yunus (10):5).

b. Aroma/bau manusia berbeda-beda ,sebagaimana diisyaratkan firman Allah berikut: 
"takalah kafiyah itu keluar [dari negri mesir], ayah mereka berkata "sesungguhnya aku mencium bau yusuf, sekiranya kamu tidak menuduhku lemah akal [tentu kamu membenarkan aku],[QS. Al-baqarah [2];23]

c. Adanya Nurani [super ego] dan bawah sadar manusia,sebagaimana diisyaratkan firman allah berikut:

" bahkan manusia menjadi saksi atas dirinya sendiri meskipun dia mengemukakan alasan-alasanya. [QS.al-Qiyamah [75];14]

d. Masa penyusuan yang tepat dan masa kehamilan minimal sebagai wara diisyaratkan firman Allah berikut" para ibu hendaklah menyusukan anak-anaknya selama dua tahun penuh, yaitu bagi yang ingin menyempurnakan penyusuhan dan kewajiban ayah memberi pakaian kepada ibu dengan cara yang makruf.” (QS. Al- baqoroh (2) :233

e. Kurangnya oksigen pada ketinggian dapat menyesakkan napas, hal ini di isyaratkan oleh firman Allah berikut:

"Barang siapa yang Allah menghendaki akan memberikan kepadanya petunjuk, niscaya Dia melapangkan dadanya untuk (memeluk agama islam ) dan barang siapa yang di kehendaki Allah kesesatannya, niscaya Allah menjadikan dadanya sesak lagi sempit, seolah-olah ia sedang mendekati langit. Begitulah Allah menimpakan siksa kepada orang-orang yang tidak beriman.” (QS.al-An'am (6) :125)

6. Ketelitian redaksinya

- Keseimbangan antara jumlah bilangan kata dengan antonimnya beberapa contoh, di antaranya :

1) Al-hayah (hidup) dan al-maut (mati), masing-masing sebanyak 145 kali;

2) An-naf (manfaat) dan Al-madharah (mudarat), masing-masing sebanyak 50 kali;

3) Al-har (panas) al-bard (dingin) masing-masing 4 kali

4) Ash-shalihat (kebajikan) dan as-sayyi'at (keburukan), Masing-masing 167 kali;

5) Ath-thuma'ninah (kelapangan/ketenangan) dan adh-dhiq (kesempitan/kekesalan), masing-masing 13 kali;

6) Ar-rabah (cemas/takut) dan ar-raghbah (harap/ingin),masing-masing 8 kali;

7) Al-Kufr (kekufuran)dan al-iman (iman) dalam bentuk definite, masing-masing 17 kali; 
8) Ash-shayt (musim panas) dan asy-syita (musim dingin), masing-masing 1 kali;

- Keseimbangan jumlah bilangan kata engan sinonimnya/makna yang di kandungnya

a) Al-harts dan az-zira'ah (membajak/Bertani), masing-masing 14 kali;

b) Al-'usb dan adh-dhurur (membanggakan diri/angkuh), masing- masing sebanyak 27 kali;

c) Adh-dhallun dan al-mawta (orang sesat/mati jiwanya),masing-masing 17 kali.

\section{Kesimpulan}

Dari kajian di atas dapat disimpulkan bahwa:

1. Al-Qur'an memiliki banyak kemukjizatan, di antaranya mukjizat dari segi bahasa ini, yaitu: susunan kata dan kalimat serta keseimbangan redaksi al-Qur'an itu sendiri, dari segi kajian ilmiah, kajian hukum dan kajian pemberitaan yang gaib.

2. Al-Qur'an sudah sangat jelas kemu'jizatannya. Namun demikian, masih ada juga hal-hal yang dipertentangkan, dipermasalahkan, dikritik yang berkaitan dengan kemukjizatan alQur'an oleh sebagaian para ilmuan, di antaranya berkaiatan dengan sistematika dan kritik terhadap bahasa al-Qur'an.

\section{Daftar Pustaka}

Dr. H. Badrudin, M.Ag,’I'jaz Al-qur'an”,Hal.135,Kota Serang

Dr. H. Badrudin, M.Ag., Ulumul Qur'an: Prinsip-prinsip dalam pengkajian ilmu tafsir al-Qur'an

H.Muh.quraish syihab dkk, sejarah \& ulum al-qur'an (Jakarta: Pustaka Firdaus, 1999), hlm.106

Quraish syihab, mukjizat al-qur'an dan aspek kebahasaan, isyarat ilmiah dan pemberitaan yang ghaib ( bandung: mizan 1998), cet.IV, hlm.23.

Manna Khalil al-qothahthahan, mabahits fiulumul qur'an diterjemahkan oleh muzakkir AS.

Dengan judul studi ilmu-ilmu al-qur'an (bogor: Pustaka lentera antar nusa, 1996), cet.III, hlm.371. 
Usman, ulumul qur'an hlm.287

Imam suyuti, ulumul qur'an terj. Al-itqon fi ulumil qur'an (Surakarta: indiva Pustaka, 2009), hlm.667

Quraish Shihab (1998). Wawasan al-Qur'an. Cet. VIII, Bandung: Mizan. 